\title{
The Ideological Orientations of Canadian University Professors
}

\author{
M. Reza Nakhaie \\ University of Windsor \\ Robert J. Brym \\ University of Toronto
}

\begin{abstract}
This paper analyzes the ideological orientations of Canadian university professors based on a unique 2000 study of a representative sample of Canadian academics $(n=3,318)$. After summarizing methodological problems with extant research on this subject, and tentatively comparing the political views of Canadian and American academics, the paper demonstrates that Canadian academics fall to the left of the political spectrum but are not hugely different in this respect from the Canadian university-educated population. Multivariate analyses reveal considerable heterogeneity in the ideological views of Canadian professors, suggesting that contemporary characterizations of the North American professoriate as left- or right-leaning tend to be overdrawn. Multivariate analyses demonstrate the importance of disadvantaged status and disciplinary socialization in shaping professors' ideological views, although selfselection processes are not discounted.

\section{RÉSUMÉ}

Cet article analyse les orientations idéologiques des professeurs des universités canadiennes selon une étude unique datant de l'an 2000 et portant sur un échantillon représentatif composé de 3318 professeurs d'université du Canada. Après avoir résumé les problèmes méthodologiques avec une recherche approfondie sur le sujet, puis tenté de comparer les vues politiques de professeurs d'universités canadiennes et américaines, l'article démontre que les professeurs d'université du Canada se situent à la gauche de l'éventail politique, sans être très différents de l'ensemble des diplômés universitaires du Canada. Les analyses multidimensionnelles révèlent une hétérogénéité considérable des vues idéologiques des professeurs canadiens, suggérant ainsi que les caractérisations contemporaines selon lesquelles le professorat nord-américain se situe soit vers la droite, soit vers la gauche, ont tendance à être à exagérées. Les analyses multidimensionnelles démontrent l'importance de la socialisation disciplinaire et du statut de défavorisé pour former les vues idéologiques des professeurs, même si les processus d'autosélection ne sont pas pris en compte.
\end{abstract}




\section{PAST RESEARCH}

Scholars have long debated whether North American academics tend toward the left or the right of the political spectrum. While the dominant view used to be that academics are mainly career-oriented and apolitical or conservative (Gouldner, 1979; Jacoby, 1987; Martin, 1998; Mills, 1959; Starr, 1995; Thomson, 1990; Turk, 2000), the contrary opinion gained ground in the 1990s, fuelled by the neoconservative movement. The dissenters held that once the radicals and activists of the 1960s and 1970s joined the ranks of the professoriate, universities moved sharply to the left. Therefore, the dissenters continued, professors now tend to vote for non-conservative political parties, sharply limit the recruitment of conservative faculty, and penalize students for holding conservative views. According to the dissenters, widespread support for political correctness, feminism, multiculturalism, and affirmative action is indicative of the radical climate in universities (Bennett 1984; Bloom 1987; D’Souza, 1991; Ferry, 1999; Gruhn ,1994; Gunter, 2001; Horowitz, 2002; Kimball, 1990; Klatt, 2000; Lipton, 1991; Rothman, Lichter, \& Nevitte, 2005a; Schratz, 1993a, 1993b; Thomson, 1990). "Velvet terrorism" is the way one University of Toronto professor describes the ideological atmosphere of university life today (quoted in Kay 2004).

Despite the vigorous debate, little systematic research exists on the ideological orientation of professors in Canada, and the corresponding lack of data prevents definitive judgements about the ideological orientation of the country's academics. This is an important shortcoming because if the academy has a strong ideological tilt, universities may fail their institutional imperatives of universalism, disinterestedness, and organized scepticism (Merton, 1973). American research conducted since Ladd and Lipset's (1975) groundbreaking work is more substantial. However, because of significant differences between Canada and the United States, we cannot safely generalize from one country to the other. For example, the United States has a stronger history of anti-intellectualism than Canada does, and the attack on universities by political officials and conservative think tanks for alleged ideological bias has been more muted in Canada than in the United States. Even ignoring such differences, much recent American research is methodologically flawed, as we shall see, so generalizing from American research is doubly hazardous.

The works of Rothman, Lichter, and Nevitte (2005a) and Ames, Barker, Booneau, and Carmen (2005) are the latest empirical contributions to the debate. Relying on the 1999 North American Academic Study Survey, Rothman et al. (2005a) concluded that a left ideological tilt exists in U.S. colleges and universities, and that political conservatives are therefore disadvantaged in professional advancement. Ames et al. (2005) countered that Rothman et al. conflate placement and advancement. Moreover, Rothman et al. fail to explain why ideology limits the advancement of some groups; to consider selection bias; and to control for religiosity, region, and community size (Rothman et al., 2005b).

Five reasons exist for disagreement on the extent, nature, and consequences of the ideological orientation of North American academics. First, most research is based on measures of Democratic versus Republican sympathies in the United States, yet these parties are complex organizations that accommodate a wide range of opinion. Some Democrats consider themselves conservative and some Republicans consider themselves liberal. Complicating the picture is the fact that liberalism and conservatism are multidimensional concepts; fiscal conservatives may be liberal on social issues such as gay rights and freedom of reproductive choice, while fiscal liberals may be conservative on social issues. Party sympathy is therefore a problematic measure of ideological position. Ideally, we would want to assess professors' ideologies by examining a variety of political, economic, and social issues that lie at the heart of political debate today.

A second problem with extant research is that much of it ignores the heterogeneity of ideological opinion in the modern university. There is good reason to believe that academic rank, gender, age, field of specialization, ethnicity, race, and other factors are associated with variation in political views. Nearly four decades ago, Ladd and Lipset showed that while American social scientists tended to prefer Democratic presidential candidates, natural science and business professors tended to prefer Republican candidates. Moreover, professors with more publications and a higher index of academic status who taught in elite universities supported Democratic candidates more often than other professors did. Some recent studies attend to a few such variations (Gross \& Simons, 2007), but most participants in contemporary debates about the ideological orientation of university professors 
ignore them. As Hamilton and Hargens (1993) note with only slight exaggeration, ideological heterogeneity among the professoriate is a fact that everyone knows but nobody talks about.

Sampling bias is a third issue that encourages caution in interpreting recent studies of the professoriate. Few analysts draw representative samples of the professoriate; many fail to acknowledge the hazards inherent in generalizing about the professoriate as a whole if one samples only, say, social scientists, historians, and philosophers who belong to professional associations (Klein \& Stern, 2005).

Fourth, few studies - even those that examine ideological orientation rather than party preference - account for potentially confounding factors. They may demonstrate the existence of bivariate associations but they rarely introduce controls that might account for those associations. As a result, they provide little or no insight into the social mechanisms that might explain the ideological proclivities of academics.

Finally, nearly all of the research is American. There are only two survey-based studies of Canadian academics' political orientation, one of which is more than 20 years old and focuses only on attitudes toward issues related to universities, not the broader society (Lennards 1990; Nakhaie \& Brym 1999). The second survey was administered in 2001 and is the data source for this investigation (Nakhaie, 2007). Given the paucity of Canadian survey-based research, it is fair to say that we know little about the ideological orientations of Canadian academics and how they compare with the general population and academics in other countries, notably the United States.

In this paper, we overcome the problems just listed by conducting multivariate analyses of the ideological orientations of Canadian professors based on a representative sample drawn in 2000. To what degree do faculty members support economic, gender, and ethnic/racial equality, and unions and union militancy, in the larger society? To what extent are ideological views homogeneous across regions, fields, age cohorts, and other social divisions? What social factors account for such heterogeneity of opinion as exists? These are the chief questions that we answer.

\section{DATA AND MEASUREMENT}

We analyze data from Nakhaie's (2001) survey of The Academic Profession in Canada. The survey included questions on socio-demographics, socio-economic background, political orientation, and attitudes toward gender and ethnic inequality. Sampling involved systematic selection of 10,000 fulltime faculty members within 12 strata based on province and size of university. The response rate was 34 percent $(n=3,318)$, which is at the high end for surveys of academics involving self-administered questionnaires (Neuman, 2006, pp. 295-296). We nonetheless tested for representativeness and were encouraged to find that the distribution of the sample was almost identical to the distribution of gender, rank, and field in the academic population. Chi-square tests revealed no difference between sample and population (see Appendix A). The analyses are based on weighted data. ${ }^{1}$ Analysis using unweighted data produced substantially similar results.

The dependent variables are derived from questions concerning support for unions (three items), union militancy (four items), economic equality (four items), gender equality (three items), and racial/ethnic equality (three items). Permitted responses formed a four-response Likert scale (strongly agree, agree, disagree, strongly disagree). Item questions are listed in Table 1. Factor analysis with varimax rotation and listwise deletion of missing cases resulted in the five factors that are also reported in Table 1. The category values for each factor were summed and new additive indices were created so that higher scores indicate stronger support for unions, militancy, economic equality, gender equality, and racial/ethnic equality. ${ }^{2}$ We excluded missing cases on these variables but computed indices as long as the respondent answered at least one of the questions.

We regressed these ideological indices on region, ethnicity, nativity, religiosity, age, gender, marital status, personal income, publication record, academic rank, and field of specialization (see Appendix B for details).

\section{Table 1}


Factor Analysis of Ideological Items

\begin{tabular}{|c|c|c|c|c|}
\hline & $\begin{array}{c}\text { Factor } \\
\text { loading }\end{array}$ & $\begin{array}{l}\text { Eigen- } \\
\text { values }\end{array}$ & $\begin{array}{l}\text { Variance } \\
(\%)\end{array}$ & $\begin{array}{l}\text { Cronbach's } \\
\text { alpha }\end{array}$ \\
\hline \multicolumn{5}{|l|}{ Support for economic equality } \\
\hline The difference between rich and poor is too great in Canada. & 0.843 & 2.716 & 67.9 & 0.840 \\
\hline $\begin{array}{l}\text { People of high income should pay a greater share of taxes than they pay } \\
\text { now. }\end{array}$ & 0.837 & & & \\
\hline Corporations should pay a greater share of taxes than they pay now. & 0.795 & & & \\
\hline $\begin{array}{l}\text { One of the country's goals should be to try to even out differences in } \\
\text { wealth between people. }\end{array}$ & 0.821 & & & \\
\hline \multicolumn{5}{|l|}{ Support for unions } \\
\hline How actively are you involved with your faculty association or union? & 0.872 & 1.876 & 62.5 & 0.678 \\
\hline How actively were you involved with your faculty association or union? & 0.855 & & & \\
\hline Are you personally in favour of faculty unionization at your university? & 0.620 & & & \\
\hline \multicolumn{5}{|l|}{ Support for union militancy } \\
\hline $\begin{array}{l}\text { There are circumstances in which a strike would be a legitimate means of } \\
\text { collective action for faculty members. }\end{array}$ & 0.833 & 2.25 & 56.2 & 0.737 \\
\hline $\begin{array}{l}\text { During a strike, management should not be allowed to hire workers to } \\
\text { take the places of striking workers. }\end{array}$ & 0.783 & & & \\
\hline Government employees should not have the right to strike. & 0.761 & & & \\
\hline $\begin{array}{l}\text { Faculty members need to be militant in order to defend their legitimate } \\
\text { interests in their place of work. }\end{array}$ & 0.604 & & & \\
\hline \multicolumn{5}{|l|}{ Support for gender equality } \\
\hline We have not gone too far in pushing for equal rights for all in this country. & 0.663 & 1.887 & 62.9 & 0.661 \\
\hline $\begin{array}{l}\text { It is important to guarantee equal opportunities between men and } \\
\text { women in all aspects of life. }\end{array}$ & 0.864 & & & \\
\hline $\begin{array}{l}\text { One of the country's goals should be to guarantee equal rights for men } \\
\text { and women. }\end{array}$ & 0.838 & & & \\
\hline \multicolumn{5}{|l|}{ Support for ethnic/racial equality } \\
\hline $\begin{array}{l}\text { Because of past discrimination, it is sometimes necessary to set targets } \\
\text { for admission to college or university for ethnic/racial minorities. }\end{array}$ & 0.802 & 2.42 & 68.1 & 0.764 \\
\hline $\begin{array}{l}\text { Federal and provincial governments should not make any special effort to } \\
\text { help ethnic/racial minorities. }\end{array}$ & 0.825 & & & \\
\hline $\begin{array}{l}\text { Federal and provincial governments should increase the employment op- } \\
\text { portunities available to ethnic and racial minorities. }\end{array}$ & 0.847 & & & \\
\hline
\end{tabular}

\section{Analysis without Controls}

We start our analysis with a cursory comparison of professors' left-right self-orientation across time. The 1987 Academic Profession Survey (Lennards 1990) and the 2000 survey, The Academic Profession in Canada (Nakhaie 2001), include the following item: "Political attitudes have often been described as being on the 'left' or on the 'right.' Does a left-right continuum make sense to you in locating your political views?" The 68.7 per cent of respondents who answered "yes" were asked to locate their political orientation on a seven-point scale. (The remaining respondents were divided between the 22.9 per cent who answered "no; does not apply" and the 8.4 per cent who replied "no; no interest in politics.")

Table 2 shows the distribution of professors' political orientations for the 68.7 per cent of respondents who located themselves on the left-right scale. We detect a slight leftward drift over time, with the mean score increasing from 4.64 to 4.89 , but the difference is within sampling error so we cannot conclude that the Canadian professoriate moved to the left between 1987 and 2000.

Table 2 . 
Left-Right Orientation of Professors, Canada

\begin{tabular}{lcc}
\hline & $\begin{array}{c}1987 \\
(\mathrm{n}=3,213)\end{array}$ & $\begin{array}{c}2000 \\
(\mathrm{n}=2,154)\end{array}$ \\
\cline { 2 - 3 } & Per cent & Per cent \\
\cline { 2 - 3 } Right 1 & 1.5 & 1.1 \\
2 & 6.1 & 4.2 \\
3 & 14.0 & 9.6 \\
4 & 15.3 & 15.0 \\
5 & 35.9 & 37.0 \\
6 & 22.8 & 26.9 \\
Left 7 & 4.4 & 6.3 \\
Total & 100.0 & $100.1^{*}$ \\
Mean & 4.6 & 4.9 \\
Std. Dev. & 1.33 & 1.26 \\
\hline
\end{tabular}

* Does not equal 100 because of rounding.

We compared the political orientations of Canadian professors with those of the Canadian adult population. The Canadian Election Study 2000 (Blais et al., 2000) contained an item asking respondents to place themselves "on the left," "at the centre," or "on the right" of the political spectrum. Of the respondents, some 18.7 per cent placed themselves on the left, 55.5 per cent at the centre, and 25.8 per cent on the right. For Canadian adults with a BA or more, the comparable percentages were 23.9, 51.8, and 24.4. To compare these results with those for the Canadian professoriate, we collapsed categories. We found that Canadian professors are more likely than Canadian adults with a BA or higher are to place themselves on the left ( 33.3 vs. 23.9 per cent) and in the middle of the ideological spectrum (61.5 vs. 51.8 per cent), and less likely to place themselves on the right (5.2 vs. 24.4 per cent). These differences are substantial but not enormous.

We have suggested that the five ideological dimensions, as measured here, are part of the political left-right ideological landscape of academics. To evaluate this assertion, we analyzed the correlation coefficients between these five dimensions and left-right political orientation. As can be seen from Table 3, all ideological dimensions are statistically related to the left-right political orientation, some moderately (gender equality and union involvement), others more strongly (union militancy, ethnic/ racial equality and economic equality). Therefore, we evaluated these five ideological aspects of the left-right political orientation. In general, the left-right measure is most strongly associated with economic equality (at about .60), followed by union militancy and ethic/racial equality (at about .47), and then by union involvement and gender equality (at about .30). Cronbach's alpha for all indices is .743 without, and .768 with, the left-right index included.

Table 3

Correlation Coefficients for Ideological Indices and Left/Right Orientation

\begin{tabular}{llllllc}
\hline & & 2 & 3 & 4 & 5 & 6 \\
\hline 1 & Union Involvement & 0.338 & 0.506 & 0.263 & 0.144 & 0.307 \\
2 & Economic Equality & --- & 0.514 & 0.461 & 0.371 & 0.602 \\
3 & Union Militancy & --- & --- & 0.390 & 0.279 & 0.465 \\
4 & Ethnic/racial Equality & --- & --- & --- & 0.388 & 0.468 \\
5 & Gender Equality & --- & --- & --- & --- & 0.294 \\
6 & Left/Right Orientation & --- & --- & --- & --- & --- \\
\hline
\end{tabular}

Note: All correlations are significant at .001

Table 4 shows means and standard deviations for the five attitudinal indices. In all of these mea- 
sures, professors scored to the left of centre. The Canadian Election Study 2000 (Blais et al., 2000) allows a rough comparison between professors' attitudes on the five ideological dimensions and those of the general population. We conducted a factor analysis of relevant items in the Canadian Election Study 2000 using varimax rotation with listwise deletion of missing cases, and arrived at five factors that are approximately the same as those just discussed. ${ }^{3}$ Means and standard deviations are reported in the bottom half of Table 4. The results suggest that, after accounting for the number of categories in each index (by dividing the mean by the range), professors and the public score about the same on economic equality - and both are left of centre. Professors score to the left of centre on all of the remaining dimensions, while the public scores slightly to the left of centre on union militancy and slightly to the right of centre on support for unions, gender inequality, and ethnic/racial inequality $(1=$ left, $0.5=$ centre, 0 = right). The biggest difference between the professoriate and the public concerns support for gender equality, but in general, the differences are less pronounced than in the United States (Gross \& Simmons, 2007; Rothman et al., 2005a; Thomson, 1990).

Table 4

Ideological Dimensions: Professors and Population

\begin{tabular}{lccccc}
\hline \multicolumn{5}{c}{ Support for... } \\
\hline Professors & Economic equality & Unions & Union Militancy & Gender Equality & Ethnic/Racial Equality \\
\hline Mean & 11.5 & & & & \\
Std. Dev. & 3.5 & 3.4 & 11.3 & 10.2 & 7.8 \\
Minimum & 1.0 & 1.0 & 1.0 & 1.0 & 2.6 \\
Maximum & 16.0 & 15.0 & 16.0 & 12.0 & 1.0 \\
n & 3,266 & 3,288 & 3,299 & 3,263 & 3,262 \\
Mean/range & 0.77 & 0.67 & 0.75 & 0.92 & 0.71 \\
\hline Population & & & & 4.8 & 4.7 \\
\hline Mean & 7.0 & 3.7 & 6.0 & 3.1 & 2.2 \\
Std. Dev. & 2.4 & 1.7 & 2.1 & 1 & 1 \\
Minimum & 1 & 1 & 1 & 12 & 11 \\
Maximum & 11 & 9 & 12 & 3,523 & 3,479 \\
$\mathrm{n}$ & 3,590 & 2,809 & 1,441 & 0.43 & 0.47 \\
Mean/range & 0.70 & 0.46 & 0.54 & & \\
\hline
\end{tabular}

\section{Multivariate Analysis}

As noted earlier, one must account for confounding variables before endorsing blanket statements about the domination of the academy by liberals or conservatives. Table 5 presents ordinary least squares regressions of our ideological indices on predictors. Given the sample size, some of the predictors are statistically significant but their effect may be trivial. Here we focus on predictors that have a consistent effect on several of the ideological dimensions and/or have a beta weight larger than .1 (for detailed analyses, see Appendix C). Using these criteria, we notice that liberal arts disciplines, particularly in the humanities and social sciences, have a strong and consistent relationship with the ideological indices. For example, the beta weight for humanities is .231 for economic equality, .164 for union involvement, .233 for union militancy, .139 for gender equality, and .172 for ethnoracial equality. Religiosity is also moderately associated with economic equality, union militancy, and gender equality. Its effects are somewhat weaker than that of the disciplines discussed above. Finally, although less consistent across ideological dimensions, older respondents are moderately less supportive of union and ethno-racial equality, males are less supportive of gender equality, high status universities are less supportive of unions, and respondents born in Canada are less supportive of ethno-racial equality. The beta weights for other variables are all below .1.

Table 5 
Support for Economic Equality, Unions, Union Militancy, Gender Equality, and Ethnic/Racial Equality by Predictors

\begin{tabular}{|c|c|c|c|c|c|c|c|c|c|}
\hline & \multicolumn{3}{|c|}{ Economic Equality } & \multicolumn{3}{|c|}{ Unions } & \multicolumn{3}{|c|}{ Union Militancy } \\
\hline & $\mathrm{b}$ & s.e. & beta & $\mathrm{b}$ & s.e. & beta & $\mathrm{b}$ & s.e. & beta \\
\hline Atlantic & $0.488^{c}$ & 0.200 & 0.048 & 0.039 & 0.178 & 0.004 & $0.389^{c}$ & 0.188 & 0.041 \\
\hline Quebec & -0.175 & 0.189 & -0.021 & 0.163 & 0.168 & 0.022 & -0.158 & 0.177 & -0.020 \\
\hline Prairies & $0.528^{\mathrm{b}}$ & 0.174 & 0.058 & 0.201 & 0.154 & 0.025 & $0.455^{\mathrm{b}}$ & 0.163 & 0.053 \\
\hline BC & $-0.580^{b}$ & 0.224 & -0.047 & -0.273 & 0.199 & -0.025 & $-0.750^{\mathrm{a}}$ & 0.210 & -0.065 \\
\hline Age & $-0.032^{\mathrm{a}}$ & 0.008 & -0.085 & $-0.041^{\mathrm{a}}$ & 0.007 & -0.123 & 0.006 & 0.008 & 0.016 \\
\hline Male & $-1.003^{\mathrm{a}}$ & 0.141 & -0.133 & -0.214 & 0.125 & -0.032 & -0.195 & 0.132 & -0.028 \\
\hline Married/cohabiting & $-0.538^{a}$ & 0.139 & -0.068 & $-0.260^{c}$ & 0.124 & -0.037 & $-0.350^{b}$ & 0.130 & -0.048 \\
\hline Visible minority & 0.154 & 0.243 & 0.013 & 0.130 & 0.215 & 0.012 & -0.105 & 0.227 & -0.009 \\
\hline Jewish ID & 0.390 & 0.267 & 0.027 & -0.274 & 0.236 & -0.022 & 0.376 & 0.249 & 0.028 \\
\hline French ID & -0.240 & 0.235 & -0.026 & -0.012 & 0.209 & -0.001 & 0.360 & 0.220 & 0.042 \\
\hline Canadian ID & $-0.409^{c}$ & 0.167 & -0.053 & $-0.389^{b}$ & 0.148 & -0.057 & -0.068 & 0.156 & -0.009 \\
\hline Other European ID & $-0.483^{b}$ & 0.188 & -0.053 & -0.306 & 0.167 & -0.038 & $-0.436^{c}$ & 0.176 & -0.051 \\
\hline Born in Canada & 0.049 & 0.141 & 0.007 & -0.060 & 0.125 & -0.010 & -0.181 & 0.132 & -0.027 \\
\hline Religiosity & $-0.439^{a}$ & 0.072 & -0.105 & $-0.198^{b}$ & 0.064 & -0.054 & $-0.553^{a}$ & 0.067 & -0.143 \\
\hline Parent's education & $-0.036^{c}$ & 0.014 & -0.044 & $-0.028^{c}$ & 0.013 & -0.040 & -0.008 & 0.013 & -0.011 \\
\hline Log income & $-0.673^{b}$ & 0.241 & -0.057 & -0.233 & 0.215 & -0.022 & $-0.582^{b}$ & 0.226 & -0.053 \\
\hline Missing income dummy & $-0.934^{\mathrm{a}}$ & 0.190 & -0.086 & $-1.122^{\mathrm{a}}$ & 0.169 & -0.117 & $-0.796^{a}$ & 0.178 & -0.079 \\
\hline Education & $1.677^{\mathrm{a}}$ & 0.268 & 0.110 & $1.310^{\mathrm{a}}$ & 0.236 & 0.099 & $1.581^{\mathrm{a}}$ & 0.249 & 0.112 \\
\hline Performing arts & $1.405^{\mathrm{a}}$ & 0.388 & 0.064 & -0.079 & 0.343 & -0.004 & 0.330 & 0.364 & 0.016 \\
\hline Humanities & $2.233^{\mathrm{a}}$ & 0.179 & 0.231 & $1.398^{\mathrm{a}}$ & 0.159 & 0.164 & $2.106^{\mathrm{a}}$ & 0.168 & 0.233 \\
\hline Social sciences & $1.928^{\mathrm{a}}$ & 0.170 & 0.208 & $1.102^{\mathrm{a}}$ & 0.151 & 0.135 & 1.707 & 0.159 & 0.197 \\
\hline Business & -0.247 & 0.245 & -0.018 & 0.015 & 0.218 & 0.001 & 0.283 & 0.230 & 0.022 \\
\hline Engineering & 0.228 & 0.273 & 0.015 & -0.222 & 0.243 & -0.016 & -0.305 & 0.256 & -0.021 \\
\hline Log publications & 0.004 & 0.046 & 0.002 & $-0.140^{\mathrm{a}}$ & 0.041 & -0.075 & -0.016 & 0.043 & -0.008 \\
\hline Rank of university & -0.212 & 0.126 & -0.034 & $-1.089^{a}$ & 0.112 & -0.196 & $-0.502^{\mathrm{a}}$ & 0.118 & -0.085 \\
\hline Full professor & -0.363 & 0.226 & -0.052 & 0.036 & 0.200 & 0.006 & -0.366 & 0.211 & -0.057 \\
\hline Associate professor & -0.111 & 0.192 & -0.015 & $0.463^{\mathrm{b}}$ & 0.171 & 0.072 & -0.025 & 0.180 & -0.004 \\
\hline Other ranks & $0.565^{c}$ & 0.280 & 0.041 & 0.002 & 0.249 & 0.000 & -0.018 & 0.262 & -0.001 \\
\hline Constant & $23.69^{a}$ & 2.779 & & $19.27^{\mathrm{a}}$ & 2.473 & & $20.9^{7} a$ & 2.601 & \\
\hline $\mathrm{N}$ & 2916.000 & & & 2942.000 & & & 2942.000 & & \\
\hline $\mathrm{R}^{2}$ & 0.180 & & & 0.163 & & & 0.173 & & \\
\hline $\mathrm{F}$ & $22.8^{\mathrm{a}}$ & & & $20.3^{\mathrm{a}}$ & & & $21.7^{\mathrm{a}}$ & & \\
\hline
\end{tabular}

Table 5. Continued. 


\begin{tabular}{|c|c|c|c|c|c|c|}
\hline & \multicolumn{3}{|c|}{ Gender Equality } & \multicolumn{3}{|c|}{ Ethnic/Racial Equality } \\
\hline & $\mathrm{b}$ & s.e. & beta & $\mathrm{b}$ & s.e. & beta \\
\hline Atlantic & 0.171 & 0.110 & 0.032 & $0.481^{\mathrm{b}}$ & 0.155 & 0.015 \\
\hline Quebec & -0.189 & 0.104 & -0.043 & 0.097 & 0.147 & 0.076 \\
\hline Prairies & 0.134 & 0.095 & 0.028 & $0.526^{\mathrm{a}}$ & 0.134 & -0.035 \\
\hline $\mathrm{BC}$ & $-0.308^{c}$ & 0.123 & -0.048 & -0.327 & 0.173 & -0.017 \\
\hline Age & $-0.016^{a}$ & 0.004 & -0.084 & -0.005 & 0.006 & -0.163 \\
\hline Male & $-0.528^{a}$ & 0.077 & -0.134 & $-0.937^{a}$ & 0.109 & -0.027 \\
\hline Married/cohabiting & -0.142 & 0.076 & -0.035 & -0.164 & 0.108 & 0.083 \\
\hline Visible minority & 0.082 & 0.133 & 0.013 & $0.768^{\mathrm{a}}$ & 0.187 & 0.071 \\
\hline Jewish ID & $0.554^{\mathrm{a}}$ & 0.146 & 0.075 & $0.773^{\mathrm{a}}$ & 0.206 & -0.081 \\
\hline French ID & -0.026 & 0.129 & -0.005 & $-0.573^{b}$ & 0.182 & -0.094 \\
\hline Canadian ID & -0.087 & 0.091 & -0.022 & $-0.552^{\mathrm{a}}$ & 0.129 & -0.084 \\
\hline Other European ID & $-0.212^{c}$ & 0.103 & -0.045 & $-0.589^{a}$ & 0.146 & 0.038 \\
\hline Born in Canada & -0.093 & 0.078 & -0.025 & 0.204 & 0.109 & -0.108 \\
\hline Religiosity & $-0.229^{a}$ & 0.039 & -0.106 & $-0.342^{\mathrm{a}}$ & 0.055 & 0.012 \\
\hline Parent's education & -0.004 & 0.008 & -0.009 & 0.008 & 0.011 & 0.022 \\
\hline Log income & 0.127 & 0.132 & 0.021 & 0.193 & 0.187 & -0.033 \\
\hline Missing income dummy & -0.191 & 0.104 & -0.034 & -0.272 & 0.147 & 0.106 \\
\hline Education & $0.400^{\mathrm{b}}$ & 0.147 & 0.051 & $1.219^{\mathrm{a}}$ & 0.206 & 0.027 \\
\hline Performing arts & 0.094 & 0.213 & 0.008 & 0.441 & 0.297 & 0.199 \\
\hline Humanities & $0.701^{\mathrm{a}}$ & 0.098 & 0.139 & $1.462^{\mathrm{a}}$ & 0.138 & 0.172 \\
\hline Social sciences & $0.465^{\mathrm{a}}$ & 0.093 & 0.097 & $1.213^{\mathrm{a}}$ & 0.131 & 0.035 \\
\hline Business & -0.108 & 0.135 & -0.015 & 0.366 & 0.190 & -0.031 \\
\hline Engineering & -0.078 & 0.150 & -0.010 & -0.368 & 0.212 & -0.008 \\
\hline Log publications & $-0.055^{c}$ & 0.025 & -0.050 & -0.012 & 0.036 & 0.024 \\
\hline Rank of university & $0.173^{c}$ & 0.069 & 0.053 & 0.117 & 0.097 & -0.075 \\
\hline Full professor & -0.220 & 0.124 & -0.061 & $-0.396^{c}$ & 0.174 & -0.026 \\
\hline Associate professor & $-0.247^{c}$ & 0.105 & -0.065 & -0.145 & 0.149 & 0.005 \\
\hline Other ranks & -0.138 & 0.153 & -0.019 & 0.052 & 0.216 & \\
\hline Constant & $10.28^{\mathrm{a}}$ & 1.524 & & $6.76^{\mathrm{b}}$ & 2.151 & \\
\hline $\mathrm{N}$ & 2917.000 & & & 2923.000 & & \\
\hline $\mathrm{R}^{2}$ & 0.087 & & & 0.151 & & \\
\hline $\mathrm{F}$ & $9.89^{a}$ & & & $18.4^{\mathrm{a}}$ & & \\
\hline
\end{tabular}

${ }^{\mathrm{a}} \mathrm{p}<.001 ;{ }^{\mathrm{b}} \mathrm{p}<.01 ;{ }^{\mathrm{c}} \mathrm{p}<.05$ 


\section{DISCUSSION AND CONCLUSION}

The broad picture that emerges from our analysis is one of considerable heterogeneity of ideological opinion. The precise combination of variables that turns out to be statistically significantly depends on which ideological dimension we examine.

In our five regression models, only three of the 28 independent variables were consistently associated with left-leaning views: being "basically opposed" to religion, teaching education, and teaching the humanities. Teaching social sciences and not identifying oneself as of "other" (non-British and non-French) European ethnic heritage were associated with the left in four of the models. The effects of eight other variables were associated with leftism somewhat more moderately and less consistently: youth, being a woman, not identifying oneself as of Canadian ethnic heritage (hence being less assimilated into the mainstream), and not disclosing one's annual income. The remaining fifteen variables performed inconsistently across the five ideological dimensions and their effects were somewhat weaker than others were.

These findings support the theory that left-leaning academics tend to be individuals who (1) are disadvantaged along one or more status dimensions (gender and age are most apparent in our study); and (2) enter disciplines that have a distinct leftist orientation and that socialize new recruits accordingly. Let us consider these issues in turn.

Left-wing ideologies generally seek to expose the injustices of privilege and improve the lifechances of the underprivileged (Brym, 1980/2010). Consequently, leftist ideologies have traditionally appealed most to underprivileged groups. That certainly appears to be the case in Canadian academia today. Female academics tend to lag behind male academics and young academics tend to lag behind their more senior colleagues in rank, income, and prestige. Unassimilated ethnic group members, especially members of visible minority groups, may be in a similar position. Moreover, insofar as leftism has traditionally tended to be associated with opposition to religion - leftists often view established religion as an ideological and organizational prop of the privileged - it is hardly surprising that opposition to religion is common among left-leaning Canadian academics. In short, individual and collective self-interests are alive and well in the halls of academe, with professors in disadvantaged positions favouring ideas and policies that would enhance their upward mobility. ${ }^{4}$

The existence of ideological differences between disciplines is hardly news (Astin, 1975, 1986; Nakhaie \& Adams, 2008; Nakhaie \& Brym, 1999; Brym \& Nakhaie, 2009). Education, the humanities and, to a lesser degree, the social sciences contain proportionately more leftists than other fields do. However, as we have shown, these disciplinary differences are to some degree independent of background factors such as gender and age. Moreover, while students are relatively undifferentiated in terms of political attitudes early in their academic careers, ideological differences between disciplines grow as students move through the system of higher education (Guimond, Begin, \& Palmer, 1989; Guimond, Palmer, \& Begin, 1989). These facts suggest that we are observing not just disciplinary differences but disciplinary socializing effects. Specifically, each discipline has a distinct approach to its subject matter, a hidden curriculum that it transmits to its members. In addition, each discipline increases the frequency and intimacy of interaction among its members through professional associations, books, journals, and conferences. By means of these interactions, students and professors develop common ideas, interests, norms, values, and intellectual styles. Finally, contact with disenfranchised actors, or at least civil society actors, tends to be more frequent among faculty members working outside the business and natural and applied sciences; those working in the business and natural and applied sciences tend to have more frequent contact with business enterprises. Relatively distinct disciplinary approaches, patterns of internal association, and external contacts help specific disciplinary cultures to crystallize (Feldman \& Newcomb, 1969; Gouldner, 1979; Ladd \& Lipset, 1975; Merton, 1973; Rootes, 1995).

Disciplinary socializing effects are not inconsistent with self-selection processes. Academically inclined students who are predisposed to the left or the right because of their early socialization may choose disciplines that are consonant with their ideological predispositions. Different disciplines then reinforce early socialization patterns (Gross \& Fosse, 2010). Although we lack data on self-selection processes, the plausible claim that they influence ideological views suggests the need for longitudinal research capable of sorting out the exact causal sequence at work and measuring the separate and combined effects of self-selection, disciplinary socialization, and status disadvantage. 
Finally, we emphasize once again that sweeping characterizations of the Canadian professoriate as "left-wing" or "right-wing" bear little correspondence to reality. More than one in three Canadian professors does not even think in left-right terms. The remainder lean to the left, but they are ideologically heterogeneous and not terribly different in their heterogeneity from the educated public as a whole. This point bears repetition because in some jurisdictions, such as the United States, some prominent politicians and think tanks have recently called loudly for curricular oversight and quota hiring that would ensure stronger representation of non-leftist ideas and personnel in the academy. In Canada, we hear fewer such calls. Nonetheless, it is well documented that the federal Conservatives have been unwilling to heed the advice of its intellectual cadres - natural and social scientists in the civil service - on the census, foreign aid, the funding of nongovernmental organizations, and other issues. It would not surprise us if their ideological predispositions eventually carry over to the academy as well, in which case it will be useful to have evidence on hand demonstrating the Canadian professoriate's diversity in the realm of ideology. $\bullet$

\section{NOTES}

1. A basic weight was first created equal to the inverse of the probability of selection for each sample record: $\mathrm{WT}=1 / \mathrm{f}=\mathrm{Nij} / \mathrm{nij}$, where $\mathrm{Nij}=$ the total population of academics in region $\mathrm{i}$ and university size stratum $\mathrm{j}$, nij = the sample population of academics in region $\mathrm{i}$ and university size stratum $j$, and $f=$ the sampling fraction. Statistical weights of the responding academics were then adjusted by uniformly distributing among them the statistical weights of non-respondents, based on the assumption that the two groups are similar in the characteristics of interest: NRCF $=$ nij / rij, where NRCF = the non-response correction factor, and rij = the number of responding academics in region i and university size strata j. Finally, population weight (POPWT) was calculated: $\mathrm{POPWT}=\mathrm{WT} * \mathrm{NRCF}$, and then a sample weight (SAMWT) was applied to the analyses: SAMWT $=$ POPWT $/$ mean of POPWT (cf. Lennards 1990). Separate analysis using unweighted data produced substantially similar results.

2. The questionnaire is available from the authors.

3. Results are available from the authors.

4. On specific ideological dimensions, we find similar effects. For example, low-income earners employed in universities of low academic rank tend to support union militancy. Members of visible minority groups are especially in favour of ethnic and racial equality. Women are inclined to favour gender equality. Our findings also suggest that the imprint of social origins remains significant, albeit weaker than some other predictors are, whether the imprint is historical (as in the case of Jews tending to support ethnic/racial equality) or biographical (as in the case of professors whose parents had low levels of education tending to support economic equality and unions).

5. The better-known Maclean's ranking scales universities within categories - primarily undergraduate institutions, institutions with medical schools and substantial $\mathrm{PhD}$ programs, and so on - but does not provide one scale for all institutions (Dwyer, 2007).

\section{REFERENCES}

Ames, B., Barker, D., Bonneau, C., \& Carman, C. (2005). Hide the Republicans, the Christians, and the women: A response to "Politics and professional advancement among college faculty." The Forum, 3(2), Art. 7. Retrieved from http://journals2.scholarsportal.info/details.xqy?uri=/15408884/ v03i0002/1075_htrtcaapaacf.xml

Astin, A. W. (1975). The power of protest: A national study of students and faculty disruption with implication for the future. San Francisco: Jossey-Bass. 
Astin. A. W. (1986). Four critical years. San Francisco: Jossey-Bass.

Bennett, W. (1984). To reclaim a legacy: A report on the humanities in higher education. Washington DC: National Endowment for the Humanities.

Blais, A., Gidengil, E., Nadeau, R., \& Nevitte, N. (2000). Canadian Election Study 2000. Retrieved from http://datalib.chass.utoronto.ca/major/election.htm.

Bloom, A. (1987). The closing of the American mind: How higher education has failed democracy and impoverished the souls of today's students. New York: Simon and Schuster.

Brym, R. (2010 [1980]). Intellectuals and politics. London: Routledge.

Brym, R., \& Nakhaie, M. (2009). Professional, critical, policy, and public academics in Canada. Canadian Journal of Sociology, 34, 655-670. Retrieved from http://ejournals.library.ualberta.ca/index. $\mathrm{php} / \mathrm{CJS} /$ issue/view/380

D’Souza, D. (1991). Illiberal education: the politics of race and sex on Campus. New York: Free Press.

Dwyer, M. (2007). Our $17^{\text {th }}$ annual rankings. Maclean's.ca. Retrieved from http://oncampus.macleans.ca/education/2007/11/08/our-17th-annual-rankings/

Feldman, K., \& Newcomb, T. (1969). The impact of college on students. San Francisco: Jossey-Bass.

Ferry, J. (1999, November 2). Hiring women because they are women is both cynical and patronizing. The Province, p. A20.

Gouldner, A. (1979). The future of intellectuals and the rise of the new class. New York: Macmillan.

Gourman, J. (1998). Gourman report: Undergraduate programs, 10th ed. NY: Princeton Review.

Gross, N., \& Fosse E . (2010). Why are professors liberal? Unpublished paper. Department of Sociology, University of British Columbia.

Gross, N., \& Simmons, S. (2007). The social and political views of American professors. Working paper. Harvard University and George Mason University.

Gruhn, R. (1994, January 30). Feminists become a threat to academic freedom; Criticism of collectivist ideology stifled on university campuses. Edmonton Journal, p. A7.

Guimond, S., Begin, G., \& Palmer, D. (1989). Education and causal attributions: The development of "person-blame" and "system-blame" ideology. Social Psychology Quarterly, 52(1),126-140.

Guimond, S., Palmer, D., \& Begin, G. (1989). Education, academic program and intergroup attitudes. The Canadian Review of Sociology and Anthropology, 26(2), 193-216.

Gunter, L. (2001, May 29). Political correctness behind hiring of academic imposter. Kingston Whig-Standard, p. 7.

Hamilton, R., \& Hargens, L. (1993). The politics of the professors: Self-identifications, 1969-1984. Social Forces, 71, 603-627.

Horowitz, D. (2002, September 5). Harvard U: No Republicans or conservatives and (few) white Christians need apply. FrontPageMagazine.com. Retrieved from http://www.frontpagemag.com/Articles/Read.aspx?GUID=010BD9E5-B9E7-4B00-B6F6-0C1D53F5F054

Jacoby, R. (1987). The last intellectuals: American culture in the age of academe. New York: Basic Books.

Kay, B. (2004, December 15). Propaganda in the classroom. National Post, p. A1.

Kimball, R. (1990). Tenured radicals: how politics has corrupted our higher education. New York: Harper \& Row.

Klatt, H. (2000, March 28). A political correction: A professor explains why he's teaching a course that will challenge the orthodoxy. The Ottawa Citizen, p. A1.

Klein, D., \& Stern, C. (2005). Professors and their politics: The policy views of social scientists. Critical Review, 17(3-4), 257-303. 
Ladd, E., \& Lipset, S. (1973). Academics, politics, and the 1972 elections. Washington, DC: American Enterprise Institute for Public Policy Research.

Ladd, E., \& Lipset, S. (1975). The divided academy: professors and politics. New York: McGraw-Hill.

Lennards, J. (1990). The academic profession in Canada. Working paper, Department of Sociology, Glendon College, York University.

Lipton, M. (1991, June 3). Is "political correctness" stifling us? Toronto Star, p. C28.

Martin, B. (1998). Academics. Tied knowledge: power in higher education. Retrieved from http:// www.uow.edu.au/arts/sts/bmartin/pubs/98tk/

Merton, R. (1973 [1942]). The normative structure of science. In R. Merton (Ed.), The sociology of science (pp. 267-278). Chicago: University of Chicago Press.

Mills, C. (1959). The sociological imagination. New York: Oxford University Press.

Nakhaie, M. (2001). The academic profession in Canada. Department of Sociology, University of Windsor.

Nakhaie, M. (2007). Universalism, ascription and academic rank: Canadian professors, 1987-2000. Canadian Review of Sociology and Anthropology 44(3), 361-386.

Nakhaie, M., \& Adam, B. (2008). Political affiliations of Canadian university professors. Canadian Journal of Sociology 33, 873-897. Retrieved from http://ejournals.library.ualberta.ca/index.php/ CJS/article/view/1036/3661

Nakhaie, M., \& Brym, R. (1999). The political attitudes of Canadian professors. Canadian Journal of Sociology 24, 329-353. Retrieved from http://www.ualberta.ca/ cjscopy/articles/nakhaie.html

Neuman, L. (2006). Social research methods: qualitative and quantitative Approaches. New York: Pearson.

Rootes, C. (1995). A new class? The higher educated and the new politics. In L. Maheu (Ed.), Social Classes and Social Movements: The Future of Collective Action (pp. 220-235). London: Sage.

Rothman, S., R. Lichter, \& Nevitte, N. (2005a). Politics and professional advancement among college faculty. The Forum, 3(1), Art. 2. Retrieved from http://www.bepress.com/forum/vol3/iss1/ art2//

Rothman, S., R. Lichter, \& Nevitte, N. (2005b). Fundamentals and fundamentalists: A reply to Ames et al. The Forum, 3(2), Art. 8. Retrieved from http://journals2.scholarsportal.info/details. xqy?uri=/15408884/v03i0002/1081_fafartaea.xml

Schratz, P. (1993a. December 19). Campus conundrum: Opinion or oppression? The Province, p. A45.

Schratz, P. (1993b, December 26). Academics question political correctness. Ottawa Citizen, p. A12.

Starr, P. (1995). Liberalism, conservatism, and the intellectuals. Lecture at the New York University Institute for the Humanities. Retrieved from http://www.princeton.edu/ starr/libcon.html Thomson, J. J. (1990). Ideology and faculty selection. Law and Contemporary Problems 53(3), 155-176.

Turk, J. L. (2000). What Commercialization means to education. In J. Turk, (Ed.), The corporate campus: commercialization and the danger to Canada's College and Universities (pp. 3-14). Toronto: James Lorimer. 


\section{CONTACT INFORMATION}

Robert J. Brym

Department of Sociology

University of Toronto

725 Spadina Avenue

Toronto, ON

M5S 2J4

rbrym@chass.utoronto.ca

M. Reza Nakhaie is a Professor of Sociology at the University of Windsor and Editor of the Canadian Review of Sociology. His areas of research include social capital and social inequality, political ideology, and higher education. He is currently working on a SSHRC-funded project on the labour-market integration of immigrants. His publications have recently appeared in the Canadian Review of Sociology, the Canadian Journal of Sociology, Canadian Ethnic Studies, Review of Radical Political Economics, and International Migration.

Robert J. Brym, FRSC, is a Professor of Sociology at the University of Toronto. He specializes in the study of political behaviour in Canada, Russia, Israel, and Palestine. His latest SSHRC-funded research project focuses on collective and state violence during the second intifada (2000-05). He has recently published in Social Forces, Political Science Quarterly, International Sociology, Sociological Theory, Studies in Conflict and Terrorism, and the British Journal of Sociology. His most recent book is Sociology as a Life or Death Issue, $2^{\text {nd }}$ Canadian ed. (Toronto: Nelson, 2011). 
APPENDIX A. FREQUENCY DISTRIBUTIONS FOR FULL-TIME FACULTY IN CANADIAN UNIVERSITIES

\begin{tabular}{lrrrrr}
\hline & \multicolumn{2}{c}{ Population (1998-99) } & & \multicolumn{2}{c}{ Sample (2000) } \\
\cline { 2 - 3 } \cline { 5 - 6 } Field & \multicolumn{1}{c}{$\mathrm{N}$} & \multicolumn{1}{c}{$\%$} & & $\mathrm{~N}$ & \multicolumn{1}{c}{$\%$} \\
\cline { 2 - 3 } Fine and Applied Arts & 2526 & 7.6 & & 224 & 6.8 \\
Humanities & 1364 & 4.1 & & 121 & 3.6 \\
Social Sciences & 5204 & 15.6 & & 504 & 15.2 \\
Engineering and Applied Sciences & 8858 & 26.5 & & 900 & 27.1 \\
Health Profession & 2691 & 8.1 & & 258 & 7.8 \\
Mathematics and Physical Sciences & 5987 & 17.9 & & 583 & 17.6 \\
Agriculture and Biological Sciences & 4291 & 12.8 & & 459 & 13.8 \\
Total & 2505 & 7.5 & & 269 & 8.1 \\
& 33426 & 100.0 & & 3318 & 100.0 \\
Gender & & & & & \\
Male & & & & & \\
Female & 24646 & 72.9 & & 2315 & 70.3 \\
Total & 9155 & 27.1 & & 980 & 29.7 \\
& 33801 & 100.0 & & 3295 & 100.0 \\
Academic Rank & & & & & \\
Full Professor & 13867 & 41.0 & & 1440 & 44.5 \\
Associate Professor & 11702 & 34.6 & & 1106 & 34.2 \\
Assistant Professor & 6647 & 19.7 & & 470 & 14.5 \\
Other & 1585 & 4.7 & & 211 & 6.8 \\
Total & 33801 & 100.0 & & 3227 & 100.0 \\
\hline
\end{tabular}

Source: Association of University and Colleges of Canada (2010). 


\section{APPENDIX B. INDEPENDENT VARIABLES}

- Region. The regional categories were Atlantic Provinces, Quebec, Ontario (the reference category), the Prairies, and British Columbia.

- Ethnicity. One survey item asked, "To which ethnic or cultural group(s) did your father's ancestors belong?" Another item asked if the respondent was a member of a visible minority group. From replies to these questions we developed a 6-category measure of ethno-racial origins: "British" (reference category), "French," "other European" "visible minority," "Jewish," and selfidentified "Canadian."

- Nativity. Respondents born in Canada were distinguished from immigrants (reference category).

- Gender. Gender was coded as male $=1$, female $=0$.

- Age. We measured age in years.

- Income. Income was measured by total personal income in thousand dollars. Preliminary analysis showed that the relationship between income and dependent variables is curvilinear. Therefore, we logged income in order to meet that linearity assumption of the regression.

- Missing income dummy. In just over 7 per cent of cases, data on income were missing. A dummy variable for missing income was included in the regression model to control for the effect of mean income substitution.

- Religiosity. We measured religiosity by asking respondents to place themselves on a 4-point scale ranging from "basically opposed to religion" (coded 1) to "deeply religious" (coded 4).

- Parents' education. We asked respondents to indicate the highest attained education of each parent and created a new variable indicating the higher of the two.

- Marital status dummies. We used reported marital status to create dummy variables representing "single" (reference category), "married," "divorced/separated/widowed," and "cohabiting" status. We found only the distinction between married/cohabiting and others to be useful.

- Publication record. Respondents' publications records were measured by applying the following weights to the various types of publications reported by respondents: published report $=2$, edited book $=3$, refereed article $=3$, article in edited books $=2$, book $=14$ (for justification, see Nakhaie, 2007; Nakhaie and Brym, 1999). The publication weights were summed and divided by 3 . This weighted measure of research productivity equals the average number of refereedarticle-equivalent publications for the last five years. Given that many professors publish little and some have high publication output, the measure was log transformed.

- Academic rank. Academic rank includes full professor, associate professor, assistant professor (reference), and others (mainly sessional appointments).

- Field of specialization. We measured field of specialization using a question about the department and faculty in which the respondent holds his or her main teaching appointment. To ensure we had enough cases for analysis in each category, we coded this variable as "education," "performing arts," "humanities," "social sciences," "business," and "engineering." The reference category combined professors of natural and medical sciences. We excluded law professors from our analysis because they comprised too few cases and we could not meaningfully combine them with any other category. We also excluded the residual category "others" because it contained such a wide variety of fields.

- University standing. Finally, in addition to the effects of individual-level variables, we were interested in the effects of one institutional-level variable - the standing of the respondent's university. We measured institutional standing using Gourman's (1998) 5-point scale of Canadian universities, the only such scale available. ${ }^{5}$ 


\section{APPENDIX C. STATISTICALLY SIGNIFICANT VARIABLES ON EACH IDEOLOGICAL DIMENSION}

Support for economic equality was significantly stronger among young, unmarried, irreligious women with relatively low income whose parents had a relatively low level of education. It was also stronger among those who did not identify themselves as of other European or Canadian ethnic heritage than among those of British ethnic heritage. Strong supporters of economic equality were significantly less likely to live in British Columbia, and significantly more likely to live in Atlantic Canada and the Prairies, than in Ontario. Professors in education, the performing arts, the humanities, and the social sciences proved to be significantly stronger supporters of economic equality than professors in the natural and medical sciences. The lowest academic rank was also significantly associated with strong support for economic equality.

Support for unions was significantly stronger among young, unmarried, irreligious academics whose parents had a relatively low level of education. It was stronger among those who did not identify themselves as of Canadian heritage. Professors in the humanities and the social sciences proved to be significantly stronger supporters of unions than professors in the natural and medical sciences. Strong union supporters also tended to be Associate Professors, to be employed in low-status universities, and to have few publications in the past five years.

Support for union militancy was significantly stronger among unmarried, irreligious academics with relatively low income. It was stronger among those who did not identify themselves as of other European heritage. Strong supporters of union militancy were significantly less likely to live in British Columbia, and significantly more likely to live in Atlantic Canada and the Prairies, than in Ontario. Professors in the humanities and the social sciences proved to be significantly stronger supporters of economic equality than professors in the natural and medical sciences. Strong supporters of union militancy also tended to teach in low-status universities.

Support for gender equality was significantly stronger among young, irreligious women. It was stronger among those who identified themselves as of Jewish ethnic heritage than of those who identified themselves as of British or other European ethnic heritage. Strong supporters of gender equality were less likely to live in British Columbia than in Ontario. Professors in education, the humanities, and the social sciences proved to be significantly stronger supporters of economic equality than professors in the natural and medical sciences. Strong supporters of gender equality tended not to be Associate Professors, but tended to be employed in high-status universities and to have few publications in the past five years.

Support for racial-ethnic equality was significantly stronger among irreligious women. It was stronger among those who identified themselves as of Jewish or visible minority heritage than of British ethnic heritage, and weaker among those who identified themselves as of Canadian or other European ethnic heritage. Strong supporters of racial/ethnic equality were significantly more likely to live in Atlantic Canada and the Prairies than in Ontario. Professors in education, the humanities, and the social sciences proved to be significantly stronger supporters of economic equality than professors in the natural and medical sciences. Full professors tended not to be strong supporters of racial/ethnic equality. 